\title{
Effect of river training on flood retention of the Bavarian Danube
}

\author{
Daniel Skublics ${ }^{1 *}$, Günter Blöschl ${ }^{2}$, Peter Rutschmann ${ }^{3}$ \\ ${ }^{1}$ Wasserwirtschaftsamt Rosenheim, Königstraße 19, 83022 Rosenheim, Germany. \\ ${ }^{2}$ Institute of Hydraulic Engineering and Water Resources Management, Vienna University of Technology, Karlsplatz 13/222, \\ A-1040 Vienna, Austria. \\ ${ }^{3}$ Chair of Hydraulic Engineering and Water Resources Management, Technische Universität München, Arcisstraße 21, 80333 Munich, \\ Germany. \\ ${ }^{*}$ Corresponding author. E-mail: daniel.skublics@wwa-ro.bayern.de
}

\begin{abstract}
The Bavarian Danube River has experienced numerous large flood events in recent years which make flood management an urgent matter. The propagation of flood waves along the river is heavily influenced by controlled and natural flood retention. Over the past centuries, natural flood retention areas were lost due to river training, and the hydraulic characteristics of the channel-flood plain system were modified. The purpose of this paper is to understand the effect of river training on the flood retention characteristics along the Bavarian Danube. Systematic two-dimensional hydrodynamic modelling shows that extreme floods are attenuated more strongly in the present state of the channel-flood plain system than they were historically. This is because the retention areas are filled later during the event, so the attenuation effect is much larger for the same magnitude of the retention volume. Natural flood retention is therefore not an effective management option for reducing extreme floods on the Bavarian Danube. Controlled flood retention measures provide a higher efficiency regarding peak attenuation to retention volume ratio. On the other hand, the delay of flood peaks due to natural retention may be beneficial for the superposition of the flood waves with contributions from downstream tributaries.
\end{abstract}

Keywords: Flood retention; Flood plain; Inundation areas; Flood management; Hydrodynamic modelling.

\section{INTRODUCTION}

After extreme flood events have occurred, loss of natural retention space due to river training is sometimes communicated as the main cause of flood damage in the public debate. As a consequence, floodplain restoration is presented as if it was a universal strategy for solving future flooding problems (e.g. American Rivers, 2016; Bund Naturschutz, 2016; EC, 2016). In fact, due to anthropogenic activities, including river training, very substantial retention volumes have been lost along the Bavarian rivers during the past 200 years (Skublics, 2014). The natural flood retention potential and its effect on flooding processes have therefore completely changed along the Danube and its tributaries (e.g. Blöschl et al., 2013; Mitková, 2002; Szolgay et al., 2008; 2011).

Changes in the flooding processes are also brought about by other factors (Hall et al., 2014). Typically, flood-rich and floodpoor time periods alternate due to the decadal dynamics of atmospheric circulation patterns, and global warming may additionally modify the magnitude and occurrence of extreme precipitation (Blöschl et al., 2015). There is also a tendency for the social-economic impacts of floods to increase due to an accumulation of assets in flood prone areas. The strengthening of flood protection tends to attract building activities which may further increase flood damage, a phenomenon which is usually referred to as the levee effect (Di Baldassarre et al., 2015; Früh et al., 2015).

All these processes are superimposed on the effects of river training and therefore complicate flood risk management decisions. Settlement pressure and highly limited space along the river corridors require decision makers to find a trade-off between natural restoration of floodplains and controlled flood retention in polders. A detailed understanding of processes and system response is needed for identifying sustainable risk management solutions.
The purpose of this paper is to understand the effect of river training on the flood retention characteristics for the case of the Bavarian Danube. Specifically, changes in the flood peak reduction along the river reach and the flood wave celerity are analysed. Historic and present day scenarios are compared by two-dimensional hydrodynamic modelling.

\section{FLOODS IN THE BAVARIAN DANUBE BASIN}

The Upper Danube basin covers most of southern Bavaria. The catchment area increases from $7588 \mathrm{~km}^{2}$ in the west to $77000 \mathrm{~km}^{2}$ at the Austrian border in the east. Tributaries from the southern alpine area and from the northern low mountain ranges join the Danube in this reach (Fig. 1).

Typical floods in the Bavarian Danube basin can be classified into summer floods and winter floods. Summer floods usually have a strong contribution from the Alpine tributaries (Iller, Lech, Isar and Inn) induced by topographically enhanced precipitation at the northern fringe of the Alps (Blöschl et al., 2013). Winter floods are usually caused by a warm front with snowmelt and rainfall on saturated or frozen soil which leads to high discharges in the northern tributaries (Naab and Regen) (LfW Bayern, 2003). Earlier snowmelt due to warmer air temperatures is already affecting runoff generation processes and therefore the occurrence of winter floods in the basin (Blöschl et al., 2011).

Floods at the Bavarian Danube therefore strongly depend on the spatial and temporal distribution of precipitation and the superposition of floods from the tributaries.

Additionally, the channel and floodplain characteristics play an important role. Until the beginning of the $19^{\text {th }}$ century most rivers in the catchment of the Bavarian Danube were little affected by river training measures and floods could freely inundate the natural flood plains. Between 1806 and 1867 the Bavarian Danube was trained in order to meliorate its plains 


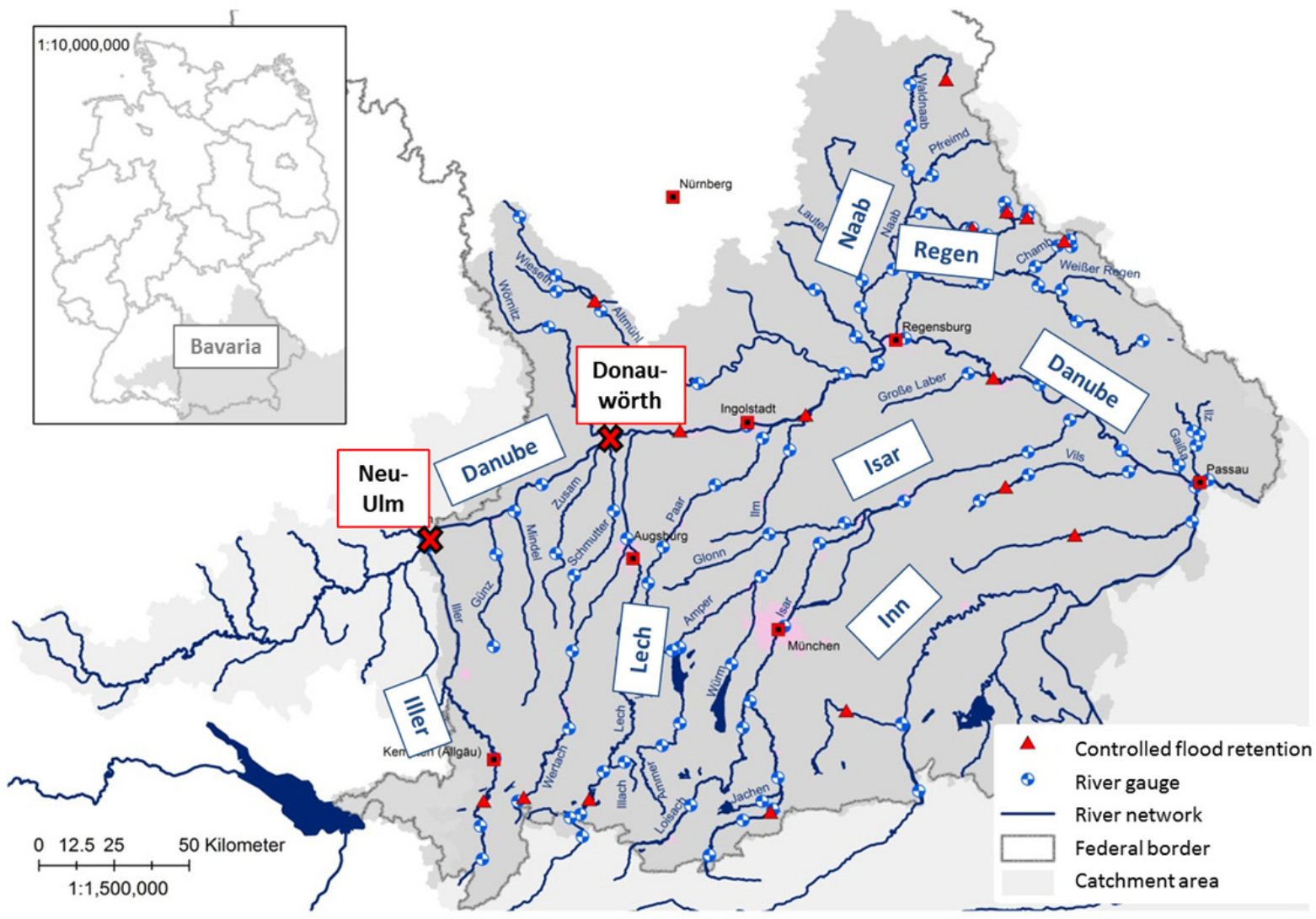

Fig. 1. Catchment of the Bavarian Danube with most important tributaries. Also indicated are large flood retention reservoirs, flood retention polders and important river gauges (from Seibert et al., 2014 (modified)).

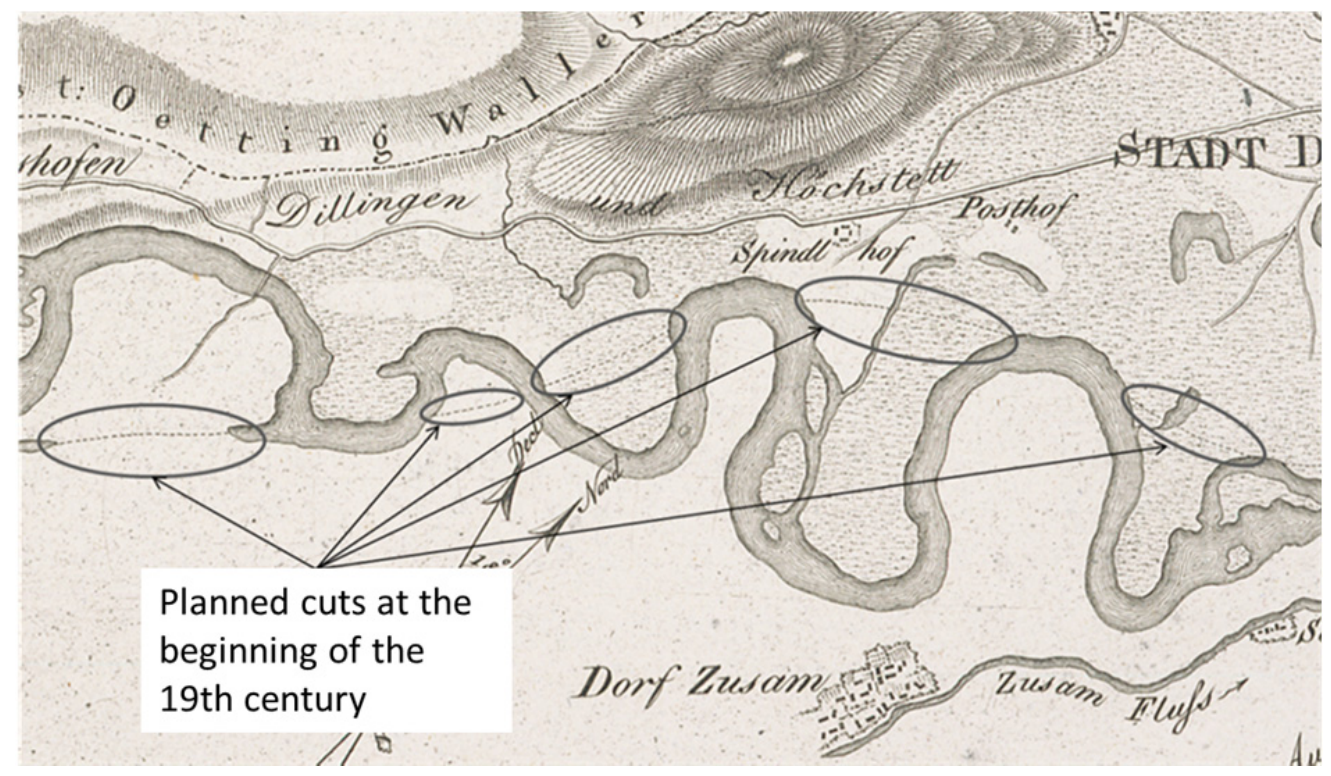

Fig. 2. Planned cuts at the beginning of the $19^{\text {th }}$ century. Danube near Dillingen (Riedl, 1808).

and to reduce the damage due to flooding. Additional benefits of the measures were enhanced inland navigation and the prevention of water borne diseases. The river works involved straightening of the river, cutting off meanders and reinforcing the river banks (see Fig. 2). The shortening of the river bed resulted in a steeper river slope, which translated in increased shear stress and consequently river bed erosion (Kern, 1874).
River bed degradation and levees built along the Danube drastically reduced the inundations along the Danube. To stop river bed erosion, barrages were built between 1953 and 1992. Hydropower plants were built to use the hydraulic head (Oberste Baubehörde Bayern, 1927). 
The anthropogenic activities have significantly reduced the retention volume available on the flood plains. Skublics and Rutschmann (2015) showed that the natural retention volume under the level corresponding to the 100-year flood discharge has been halved. Over a reach of $265 \mathrm{~km}$, approximately 350 million $\mathrm{m}^{3}$ have been lost, corresponding to a loss of 1.3 million $\mathrm{m}^{3}$ per kilometre.

Today there exist a number of controlled flood retention reservoirs in the catchment of the Bavarian Danube that differ considerably with respect to their size and technical aspects. These retention reservoirs are being optimized and new retention polders are being planned (Seibert et al., 2014). Currently, the controlled retention measures total a volume of 150 million $\mathrm{m}^{3}$, with an additional 135 million $\mathrm{m}^{3}$ being planned (Asenkerschbaumer et al., 2012).

Obviously, the anthropogenic changes over the last two centuries have very significantly affected the flood processes along the river. Today, inundation of the former floodplains only occurs at extremely high water levels. As a result, both flood wave propagation and the superposition of flood waves from the tributaries have been modified (Haider and Vischer, 1994).

\section{METHODS}

To address the question of the effects of river training on flood wave propagation and retention, hydrodynamic simulations were performed in this study. Currently, most large scale flood routing studies are carried out with hydrological or onedimensional hydrodynamic models, but these are not necessarily able to represent flood plain retention accurately (Bauer, 2004; Dimitriadis et al., 2016; Marenbach, 2002). Therefore, two-dimensional modelling was adopted here.

Along the Bavarian Danube a number of 2d-hydrodynamic models are available thanks to investigations for the Bavarian water management authorities. These models are set up in HYDRO_AS-2d (Nujic, 2002), which is a commercial 2dhydrodynamic software based on the two dimensional shallow water equations solved by a finite volume approach. The models were designed for large-scale investigations, hence the grid resolution of these models is adapted to provide relatively short computation times, while preserving enough accuracy where needed to adequately represent the hydrodynamic processes.
The model topographies are based on a DEM (digital elevation model) derived from airborne laser scanning data of the topography at a $1 \times 1 \mathrm{~m}$ resolution (altimetric accuracy $+/-0.10$ $\mathrm{m}$ to $0.15 \mathrm{~m}$ ) and river cross sections at $200 \mathrm{~m}$ intervals. An overall topographic model of the entire Bavarian Danube was developed by compiling different river reaches. Calibration and validation simulations were carried out with the hydrodynamic model, comparing observed water levels, inundation areas and discharge hydrographs from several flood events with the simulations (Asenkerschbaumer et al., 2012; Skublics and Rutschmann, 2015).

Starting from this overall model, a historical DEM for a 265 $\mathrm{km}$ river reach (between Neu-Ulm and Straubing) was developed representing the terrain before river regulation around the year 1800 (Fig. 3). The river course was derived from the historical maps of Adrian von Riedl (1808), and the historic river bed elevation was determined at specific locations from historic sources (e.g. Kern, 1874). Additionally, reports from the operators of the river barrages provided the erosion and sedimentation rates during the time between river training and construction of the hydropower plants (RMD, 1956-1981). The DEM follows a historic river slope from $0.55 \%$ in the west to $0.3 \%$ in the east, while, today, the slope varies between $0.75 \%$ and $0.4 \%$. Additionally, all levees, weirs and also the major traffic routes were eliminated from the DEM. Finally, the land use was adapted according to the historical records from mainly agricultural use today to $84 \%$ grassland on the floodplains in 1800 (LfU Bayern, 1999).

The effect of natural flood retention is nonlinear and strongly depends on the flood characteristics and other parameters (Skublics and Rutschmann, 2015). Therefore, a systematic investigation based on a spectrum of different flood events is required. A total of 20 reconstructed flood events between 1845 and 1965 (Unbehauen, 1971) and recently recorded flood events (1999, 2002 and 2005) at seven gauges along the Bavarian Danube were analysed. In a first step, the event hydrographs were intersected with the 1-year flood discharge to obtain the event volumes exceeding the 1-year flood discharge which were deemed relevant for flood retention. These volumes were normalised by the catchment area resulting in a runoff depth for each hydrograph. In a second step, all hydrographs were pooled and grouped into slim, medium and wide hydrographs.

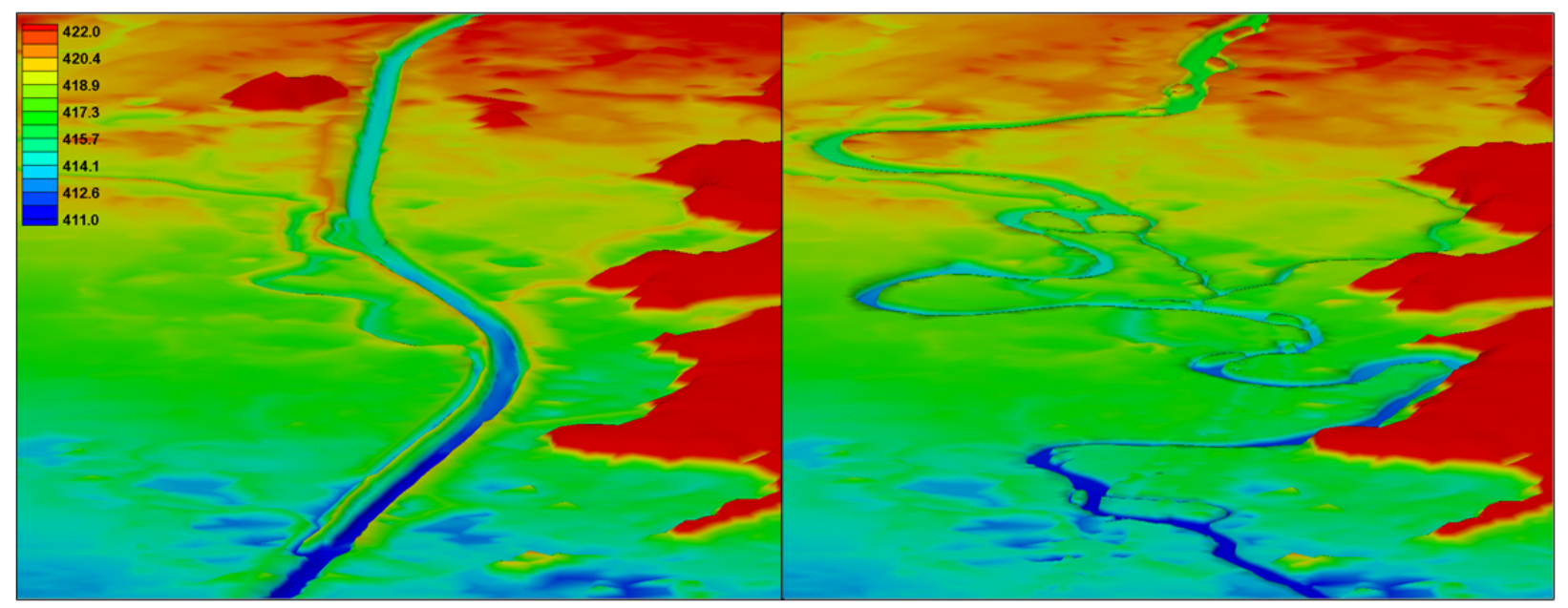

Fig. 3. DEM of the Bavarian Danube (near Donauwörth); Current state (left) and historical state around 1800 (right). Colours show topographic elevation (m a.s.1.). 


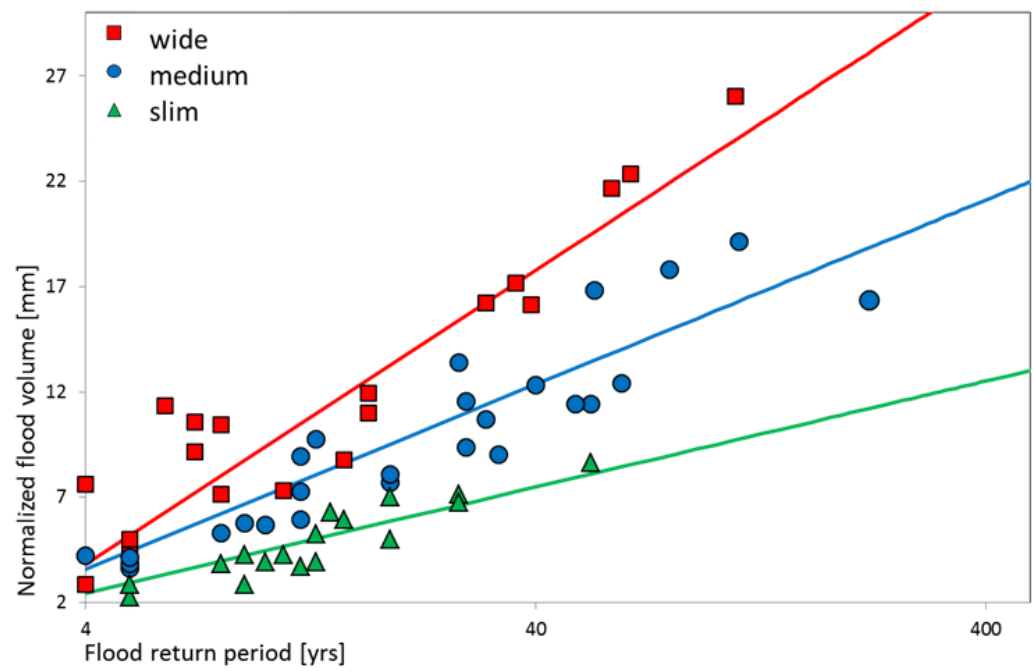

Fig. 4. Relationship between flood volume and return period (log-scale). Observed flood events; time series: 1845 to 1965 and resent flood events 1999, 2002 and 2005. The flood volume was normalized by catchment area. Regression lines for wide (red), medium (blue) and slim (green) hydrographs are shown.

The grouping was based on singling out slim summer events (smaller runoff depth than half the events), wide winter events (larger runoff depth than half the events), which left a third group of intermediate or mixed events. In a third step, the runoff depths (i.e. normalized flood volumes) of the hydrographs were plotted against the return period of the flood peak (Fig. 4). The figure shows the grouping into typical winter floods which are wide, typical summer floods which are slim, and a medium or mixed group. From these three groups, regression lines were estimated as indicated in Fig. 4. In a fourth step, synthetic hydrographs were constructed by using the modified 2-parameter Maxwell distribution as the shape of the hydrographs. The time-to-peak parameter was estimated by fitting the modified Maxwell distribution to observed hydrographs. The volume parameter was obtained from the regressions in Fig. 4. Finally, the synthetic hydrographs were scaled to the peak discharge of a given return period estimated by flood frequency analysis. The return periods were varied between 1 and 1000 years. This procedure resulted in a total of 24 synthetic hydrographs for each gauge.

The synthetic hydrographs were used as hydrologic inflow boundary conditions of the hydrodynamic models in the present and the historic states. At the gauges, the respective flood hydrographs were prescribed and the lateral inflows downstream until the following gauge were assumed to be negligible. The computed results were compared with a reference scenario where flood plain inundation was not allowed, i.e. the entire flood water was routed through the channel. Reference scenarios were simulated both for the present and for the historic states. To quantify the retention effect, the peak discharge $\left(\mathrm{Q}_{\max }\right)$ and the time when peak discharge was reached $\left(\mathrm{t}\left(\mathrm{Q}_{\max }\right)\right)$ were evaluated. From these data, the normalized attenuation $\alpha\left(\mathrm{Q}_{\max }\right)$ and the normalized delay $\delta\left(\mathrm{Q}_{\max }\right)$ of the flood waves due to retention effects were calculated according to Equations 1 and 2.

$\alpha\left(Q_{\max }\right)[-]=\frac{Q_{\max }\left[\frac{m^{3}}{s}\right]}{Q_{\max , \text { ref }}\left[\frac{m^{3}}{\mathrm{~s}}\right]}$
$\delta\left(Q_{\max }\right)[-]=\frac{t\left(Q_{\max }\right)[h]}{t\left(Q_{\max , \text { ref }}\right)[h]}$
Additionally, the respective activated retention volumes and the areas were evaluated as the differences from the reference scenario.

\section{RESULTS}

For clarity only the results for two retention areas (retention area 1: "schwäbisches Donaumoos" and retention area 2: "Riedstrom") are presented in this paper (Figs. 5 and 6). They are situated along the river reach between Neu-Ulm and Donauwörth (see Fig. 1). In the present state (Fig. 5) the retention area 1 is only filled during major flood events (beyond a 20year flood discharge) due to the river bed erosion since river regulation. In the eastern part (retention area 2), flood plain inundation occurs frequently (beyond a 5 -year flood discharge). The eastern basin forms a kind of bypass on the floodplain over a length of $40 \mathrm{~km}$. In the historic state (Fig. 6) the river overflows its banks at relatively low discharges (below a 1-year flood discharge) and almost the entire river valley is inundated. Moreover it can be seen that overflowing into the flood plains not only takes place at several locations, as it does in the present state, but it is distributed along the whole river reach. For a 100 -year flood event, the loss of retention volume through river regulation (estimated as the difference of the historic and present day retention volumes for the medium synthetic hydrograph) in the two retention areas is almost 100 million $\mathrm{m}^{3}$.

Fig. 7 shows the normalized attenuation (left column) and the normalized delay (right column) of the various hydrographs separately for retention area 1 (top) and retention area 2 (middle) as well as a combination of both (bottom).

The slim hydrographs always give greater attenuation than the medium and wide hydrographs. In the historic state, early flooding of the flood plains causes strong attenuation of the flood peak for the small floods (return periods of a few years). As the return period increases, the attenuation remains about the same, indicating that no additional retention effects occur. In contrast, in the present state peak attenuation only starts at high peak discharges and gets significantly stronger with increasing flood magnitudes. Small flood events are attenuated more strongly in the historic state while large floods are attenuated more strongly in the present state. 


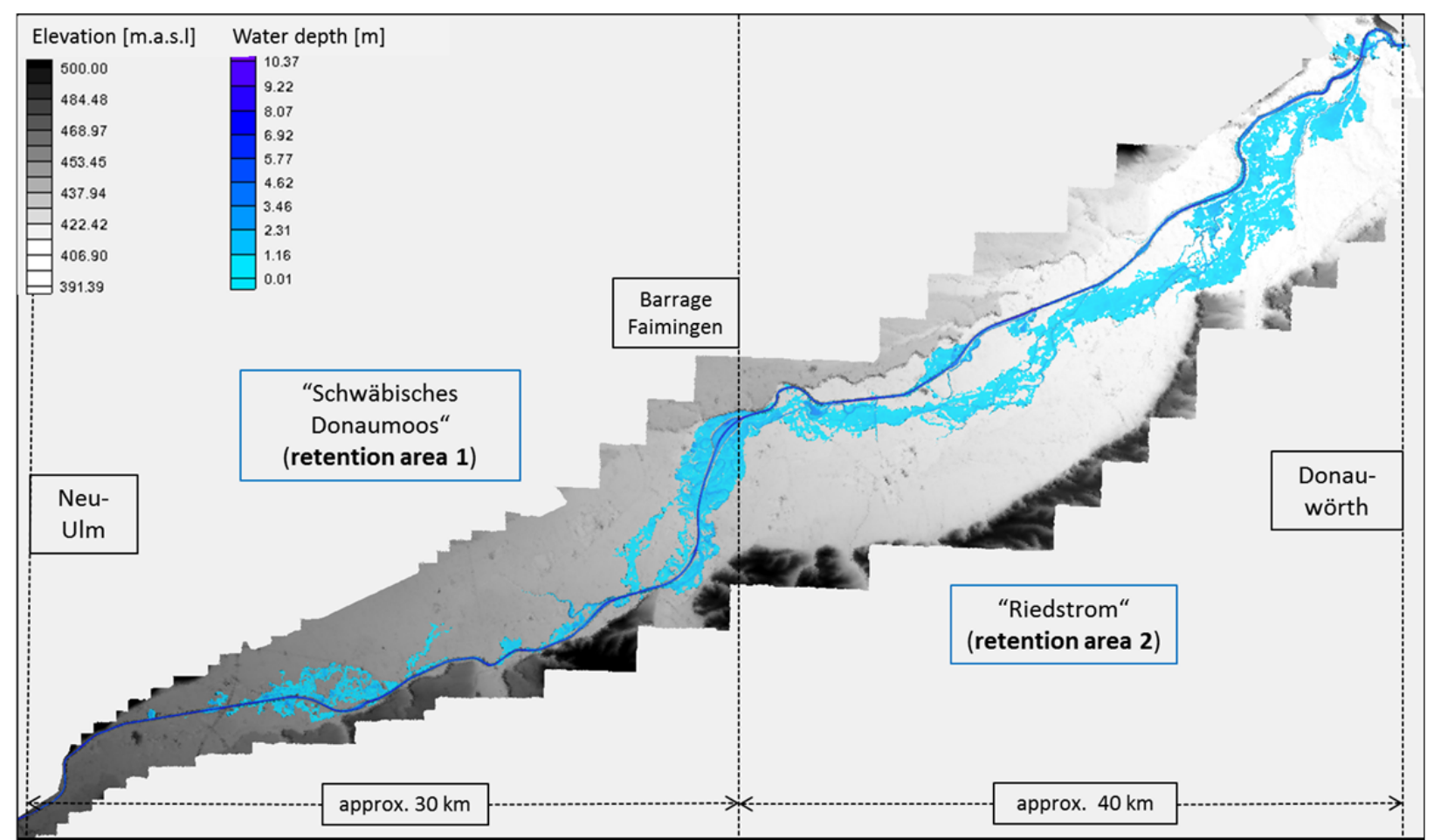

Fig. 5. Retention areas at the Bavarian Danube between Neu-Ulm and Donauwörth for a 100 year flood (synthetic flood wave; medium) in the present state.

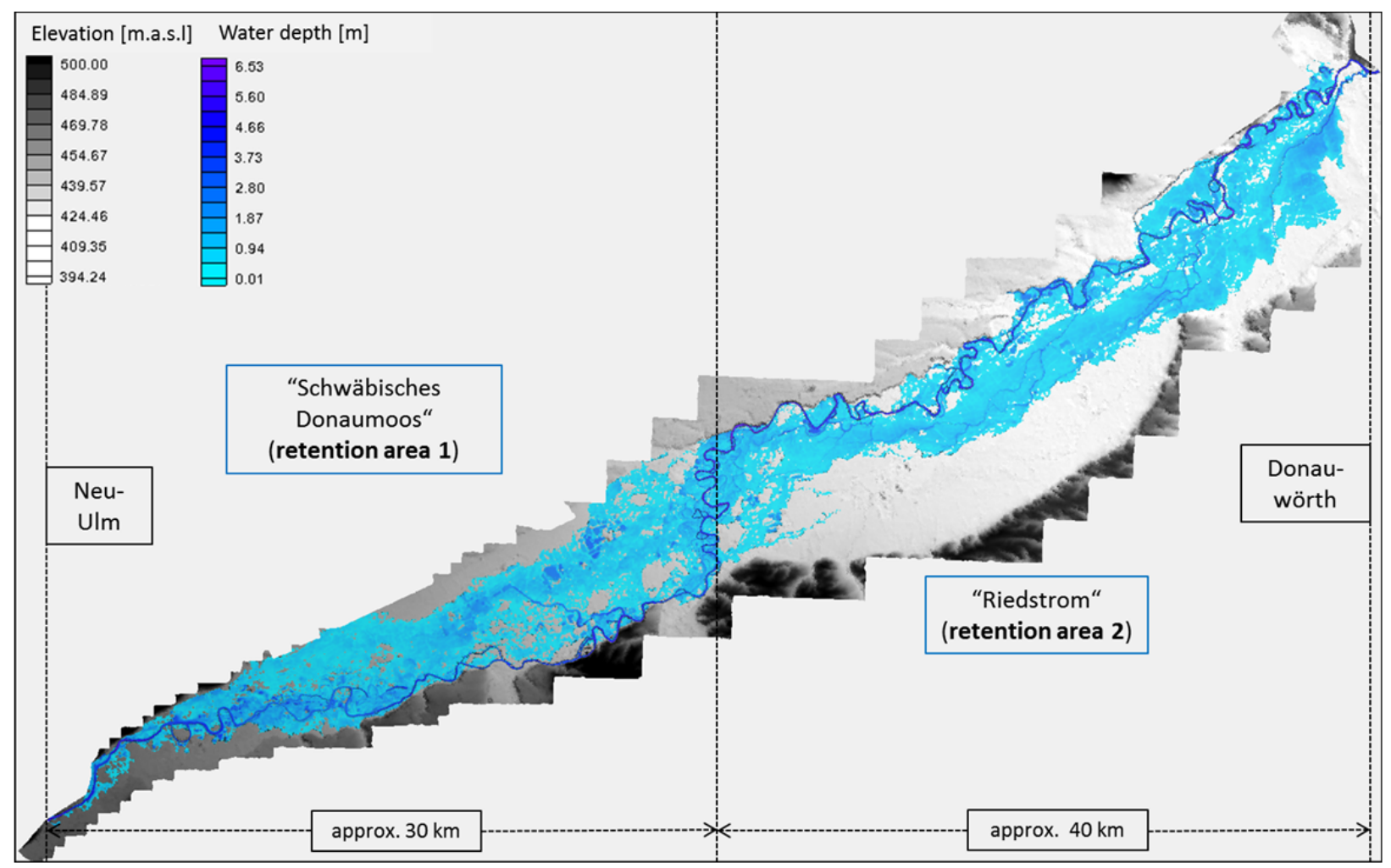

Fig. 6. Retention areas at the Bavarian Danube between Neu-Ulm and Donauwörth for a 100 year flood (synthetic flood wave; medium) in the historic state.

The flood peak delay also increases with increasing return periods in the present state, while there is almost no change in the delay with return period in the historic state. The latter behaviour is related to the strongly meandering character of the historic river course. Furthermore, it has to be emphasized that the time delays were normalized with respect to the 


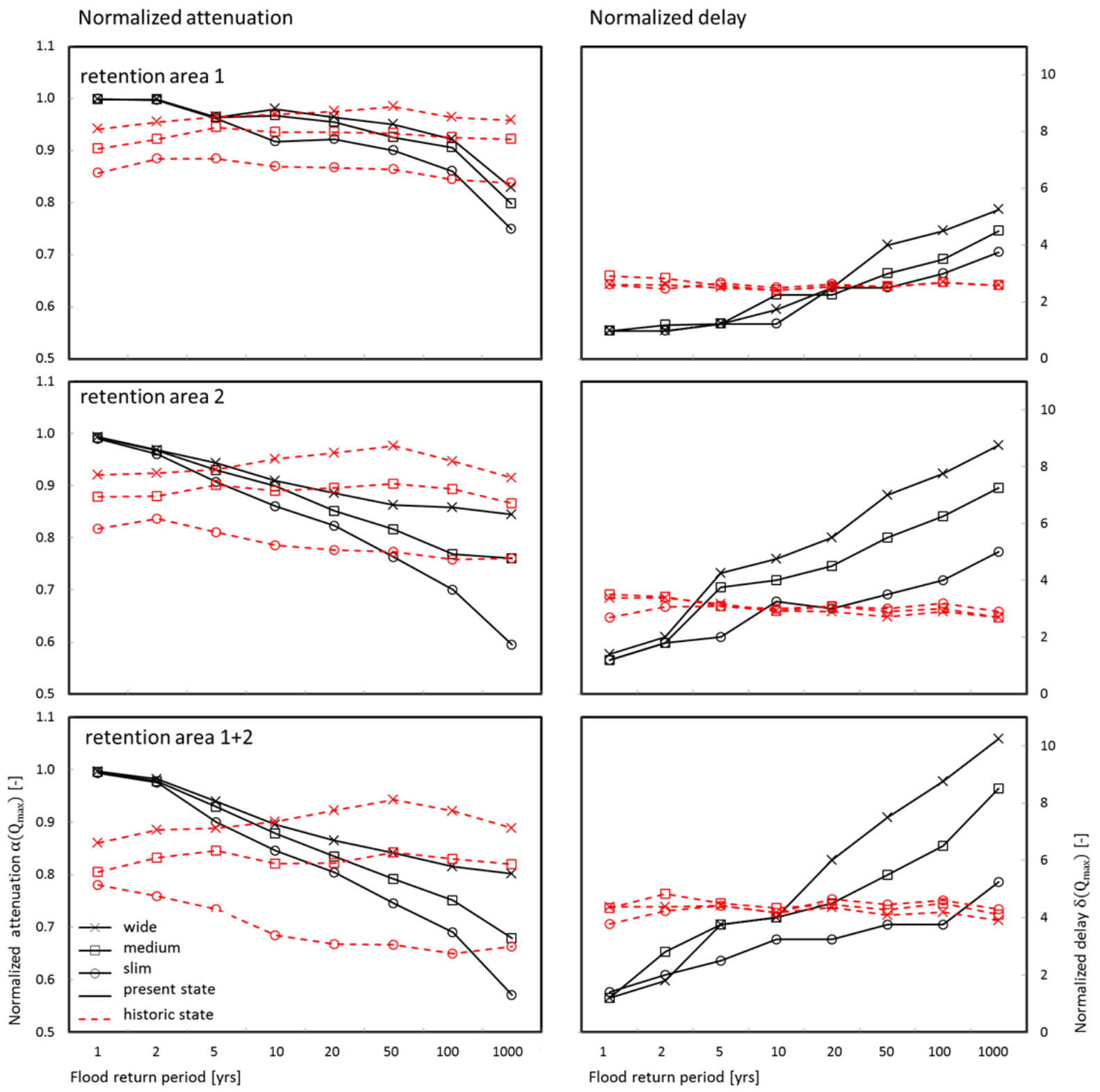

Fig. 7. Flood peak attenuation (left) and flood peak delay (right) separately for retention area 1 (top) retention area 2 (middle) and a combination of both (bottom) plotted against the flood return period of the peaks of the synthetic hydrographs. Solid (black) and dashed (red) lines indicate present and historic states, respectively. Wide (x), medium ( $\square$ ) and slim (o) hydrographs. Attenuation and delay shown here have been normalised by the respective values of the reference scenario (without flood plain inundation) according to Eqs. 1 and 2.

reference scenario of no flood plain activation. The absolute delay time in the historic state is more than twice that of the present state due to the greater length and smaller slope of the main channel.

The combined effect of the two retention areas is larger than the individual effects as would be expected (Fig. 7). The figure also clearly shows that the effect of flood retention is not simply a linear superposition of the individual effects of retention areas 1 and 2. Inundation processes of retention area 1 have an influence on when and in which way overflow into retention area 2 occurs, so the effects are more complex. An analysis of the activated retention volumes suggests that flood peak attenuation is not uniquely related to the magnitude of the volumes (Fig. 8). Equally important are the timing and the way how the retention area is filled. An increase in the retention volume but little increase in the retention area with the flood magnitude (as is the case for large floods in the historic case) produces little extra retention effect. On the other hand, if new retention area is activated (as is the case for the present state) the retention effect will still increase with increasing flood magnitudes.

These differences in the attenuation are due to the timing when the retention areas are filled. If the retention areas are filled early during an event (as is the case in the historic state), there will be little volume left at the time of the peak when it is most important for flood peak attenuation. In contrast, in the present state, the retention areas are filled later during the event, so the attenuation effect is larger for the same magnitude of the retention volume. Additionally, the characteristics of how the flood plains are inundated differ between the historic and the present states. Whereas in the historic state the overflowing of the banks into the flood plains took place extensively along the whole river, today overflowing is locally more restricted and retention areas are often isolated from the main river which will also increase the retention effect. 

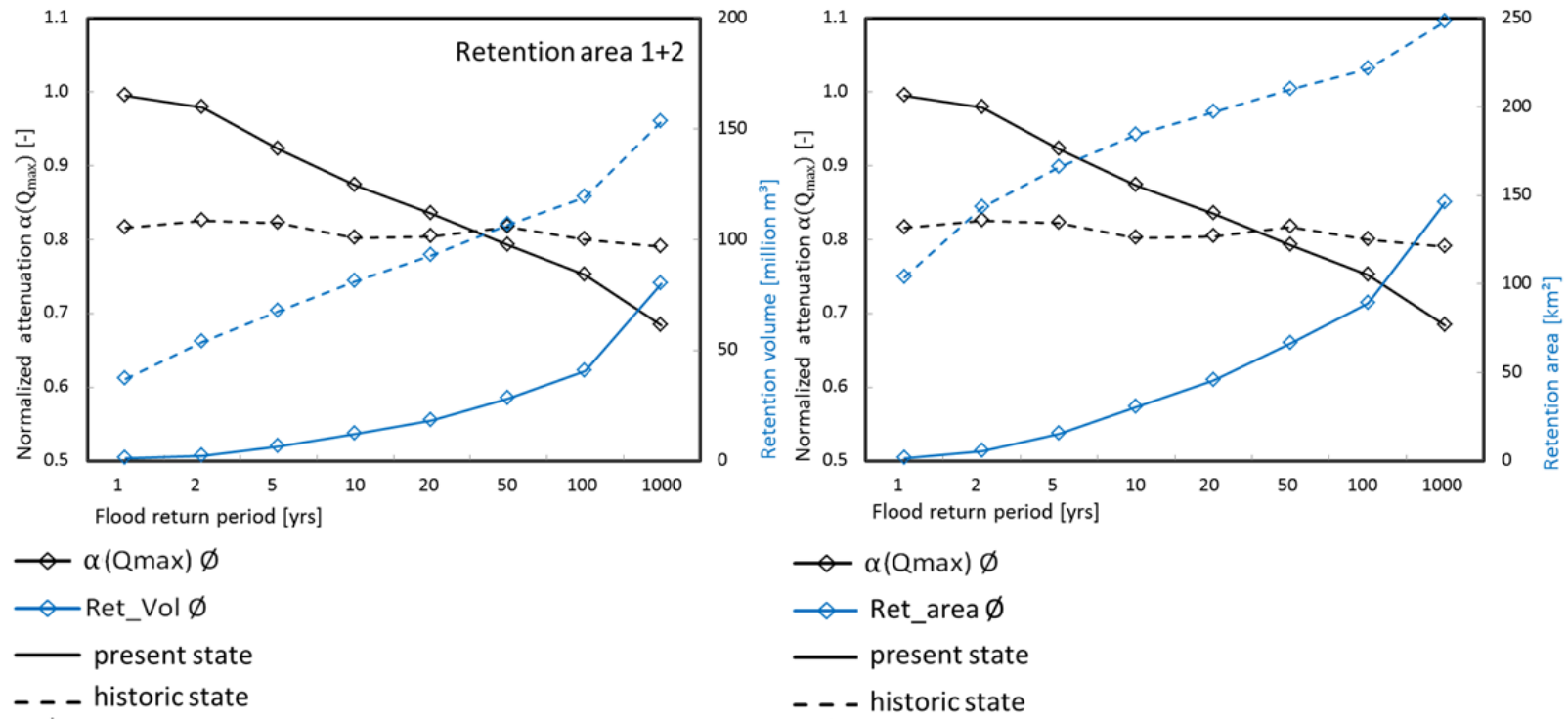

Fig. 8. Activated retention volume (left) and activated retention area (right) plotted against the flood return period. Average flood peak attenuation for the present and the historic states are shown.

\section{CONCLUSIONS}

Floods at the Bavarian Danube have significantly been affected by human activities. On the one hand, reservoirs and river barrages directly interfere with flood wave propagation. On the other hand, river training and regulation have led to a substantial loss of flood plain retention volume and to a modification of the dynamics in the channel-flood plain system.

A two-dimensional hydrodynamic approach is adopted in this paper which accurately reproduces the processes of flood retention and the changes due to river regulation and river training. The results show that the magnitude of the flood peak retention does not only depend on the retention volume but also on the timing when and how this volume is activated. The results also show that, despite the reduction of retention volume, peak attenuation of extreme floods today is larger than it was before river regulation. This is mainly due to the more efficient activation of the available retention space. Of course, the exact magnitude of the retention effect will depend on the characteristics of both the retention area and the flood hydrographs which need to be considered in detail for any case study.

Overall, these findings indicate that the effect of natural flood retention on extreme flood events is often overestimated. Natural flood retention is not an effective management option for reducing extreme floods at the Bavarian Danube. Controlled flood retention polders, however, can provide additional flood protection since retention space can be activated in a more effective way close to the time of the peak. They provide the highest peak attenuation to volume ratio, and are therefore more effective than natural retention areas. The degree to which peaks can be attenuated then mainly depends on the volume of the flood hydrographs (Fischer, 2008, Huang et al., 2007) and the ability of forecasting the flood hydrographs well. Along the Bavarian Danube a high degree of flood protection has already been achieved. Additional measures should therefore particularly focus on extreme flood events beyond the design discharges (overload scenarios).

Depending on the arrival times of flood peaks from different catchments and their superposition at confluences, an additional peak attenuation effect may be achieved by optimising the timing of the waves from different tributaries. However, such optimization requires accurate flood forecasts and regulated schemes. If the forecasts are less than perfect, management may even increase the flood peaks below confluences.

Existing natural retention areas should be protected and maintained. However, restoring additional natural retention areas may, in fact, increase the flood peaks beyond the present state, so needs to be considered with caution. The combination of both strategies, establishing controlled flood retention polders for overload scenarios and maintaining existing natural retention areas, will ensure a resilient flood protection system both for regular and extreme floods.

\section{REFERENCES}

American Rivers, 2016. http:/www.americanrivers.org/ initiatives/floods/flood-protection/ Accessed 29 March 2016

Asenkerschbaumer, M., Skublics, D., Rutschmann, P., 2012. Verzögerung und Abschätzung von Hochwasserwellen entlang der bayerischen Donau. [Estimation and delay of flood hydrographs at the bavarain Danube]. Technische Universität München, Munich. (In German.)

Bauer, C., 2004. Bestimmung der Retentionspotenziale naturnaher Maßnahmen in Gewässer und Aue mit hydraulischen Methoden. [Determination of the retention potential of near nature measures using hydraulic methods]. Herkules-Verl., Kassel. (In German.)

Blöschl, G., Viglione, A., Merz., R., Parajka, J., Salinas, J., Schöner, W., 2011. Auswirkungen des Klimawandels auf Hochwasser und Niederwasser. [Climate impacts on floods and low flows]. Österreichische Wasser- und Abfallwirtschaft, 63, 1-2, 21-30. (In German.)

Blöschl, G., Nester, T., Komma, J., Parajka, J., Perdigão, R.A.P., 2013. The June 2013 flood in the Upper Danube basin, and comparisons with the 2002, 1954 and 1899 floods. Hydrology and Earth System Sciences, 17, 51975212.

Blöschl, G., Gaál, L., Hall, J., Kiss, A., Komma, J., Nester, T., Parajka, J., Perdigao, R., Plavcova, L., Rogger, M., Salinas, J.L., Viglione, A., 2015. Increasing river 
floods: fiction or reality? Wiley Interdisciplinary Reviews: Water. doi: 10.1002/wat2.1079.

Bund Naturschutz, 2016. http://www.bundnaturschutz.de/donau/sanfter-ausbau.html Accessed 29 March 2016

Di Baldassarre, G., Viglione, A., Carr, G., Kuil, L., Yan, L. Brandimarte, K., Blöschl, G., 2015. Debates - Perspectives on socio-hydrology: Capturing feedbacks between physical and social processes. Water Resour. Res., 51, 4770-4781. doi: 10.1002/ 2014WR016416.

Dimitriadis, P., Tegos, A., Oikonomou, A., Pagana, V., Koukouvinos, A., Mamassis, N., ... AND Efstratiadis, A., 2016. Comparative evaluation of $1 \mathrm{D}$ and quasi-2D hydraulic models based on benchmark and real-world applications for uncertainty assessment in flood mapping. Journal of Hydrology. 534, 478-492.

EC, 2016. http://ec.europa.eu/environment/water/adaptation/ ecosystemstorage.htm Accessed 29 March 2016.

Fischer, M., 2008. Ungesteuerte und gesteuerte Retention entlang von Fließgewässern. [Controlled and uncontrolled retention measures along river systems]. In: Berichte des Lehrstuhls und der Versuchsanstalt für Wasserbau und Wasserwirtschaft der Technischen Universität München, Heft Nr. 119, Munich. (In German.)

Früh, A.J., Wegmann, M., Koellner, T., 2015. Flood exposure and settlement expansion since pre-industrial times in 1850 until 2011 in north Bavaria, Germany. Regional Environmental Change, 15, 1, 183-193. doi: 10.1007/s10113-0140633-9.

Haider, S., Vischer, D., 1994. Der Beitrag von Vorlandüberflutungen zur Verformung von Hochwasserwellen. [The contribution of floodplain inundation on the deformation of flood hydrographs]. Mitteilungen der Versuchsanstalt für Wasserbau, Hydrologie und Glaziologie der Eidgenössischen Technischen Hochschule Zürich, Heft Nr. 128. ETH, Zurich. (In German.)

Hall, J., Arheimer, B., Borga, M., Brázdil, R., Claps, P., Kiss, A., Kjeldsen, T.R., Kriaučiūnienè, J., Kundzewicz, Z.W., Lang, M., Llasat, M.C., MacDonald, N. ,McIntyre, N., Mediero, L., Merz, B., Merz, R., Molnar, P., Montanari, A., Neuhold, C., Parajka, J., Perdigão, R.A.P., Plavcová, L., Rogger, M., Salinas, J.L., Sauquet, E., Schär, C., Szolgay, J., Viglione, A., Blöschl, G., 2014. Understanding flood regime changes in Europe: a state of the art assessment. Hydrology and Earth System Sciences, 18, 2735-2772. doi: 10.5194/hess-18-2735-2014.

Huang, S., Rauberg, J., Apel, H., Disse, M., Lindenschmidt, K.E., 2007. The effectiveness of polder systems on peak discharge capping of floods along the middle reaches of the Elbe River in Germany. Hydrology and Earth System Sciences, 11, 4, 1391-1401.

Kern, R., 1874. Die Correktion der Donau im RegierungsBezirke Schwaben und Neuburg, Königreich Bayern: Mit 10 Flußkarten. [The correction of the Danube river at the administrative district of Swabia and Neuburg]. Kolb, Dillingen.

LfU Bayern, 1999. Gesamtökologisches Gutachten Donauried: Schwäbisches Donautal zwischen Neu-Ulm und Donauwörth. [Overall ecologic report Danauried]. Bayerisches Landesamt für Umwelt (Hrsg.), Munich. (In German.)
LfW Bayern, 2003. Hochwasser Mai 1999, Gewässerkundliche Beschreibung. [Flood May 1999, Hydrographic Description]. Bayerisches Landesamt für Wasserwirtschaft (Hrsg.), Munich. (In German.)

Marenbach, B., 2002. Der Beitrag naturnaher Retentionsmaßnahmen in den Talauen zur Hochwasserdämpfung. [The contribution of near nature flood retention measures on flood damping]. Berichte des Fachgebiets Wasserbau und Wasserwirtschaft der Universität Kaiserslautern, Heft Nr. 13. (In German.)

Mitková, V., 2002. Travel time changes of the flood on Danube River. Acta Hydrol. Slovaca, 3, 20-27.

Nujic, M., 2002. Hydro_As-2d, Ein zweidimensionales Strömungsmodell für die wasserwirtschaftliche Praxis, Benutzerhandbuch. [Hydro_AS-2d, a two-dimensional flow model, manual]. , Nujic, Kolbermoor. (In German.)

Oberste Baubehörde Bayern, 1927. Der Hochwasserschutz an der Donau in Bayern. [Flood protection at the bavarian Danube]. In: Staatsministerium des Innern Bayern (Hrsg.), Munich. (In German.)

Riedl, A., 1808. Donaustrom von der Schwäbischen Gränze durch Baiern bis an die Oesterreichische. [Danube river from the swabian tot he austrian border].In: Stromatlas von Baiern. Munich. (Bayerische Staatsbibliothek München, Signatur: 2 Mapp. 152 qe-I).

RMD, 1956-1981. Erläuterungsbericht für die Donaustufen. [Explanatory report Danube barrages]. Rhein-Main-Donau A.G., Munich. (In German.)

Seibert, S.P., Skublics, D., Ehret, U., 2014. The potential of coordinated reservoir operation for flood mitigation in large basins - A case study on the Bavarian Danube using coupled hydrological-hydrodynamic models. Journal of Hydrology, 517, 1128-1144. doi: 10.1016/j.jhydrol.2014.06.048.

Skublics, D., 2014. Großräumige Hochwassermodellierung im Einzugsgebiet der bayerischen Donau: Retention, Rückhalt, Ausbreitung. [Large scale flood modelling at the bavarian Danube catchment]. 2014. Berichte des Lehrstuhls und der Versuchsanstalt für Wasserbau und Wasserwirtschaft Band 131. Technische Universität, Munich. ISBN 987-3-34368307-3. (In German.)

Skublics, D., Rutschmann, P., 2015. Progress in natural flood retention at the Bavarian Danube. Natural Hazards, 75, S51-S67. doi: 10.1007/s11069-014-1148-x.

Szolgay, J., Danáčová, M., Jurčák, S., Spál, P., 2008. Multilinear flood routing using empirical wave-speed discharge relationships: case study on the Morava River. J. Hydrol. Hydromech., 56, 213-227.

Szolgay, J., Danáčová, M., Súrek, S., 2011. Estimation of changes of the flood regime caused by river engineering works using multilinear flow routing, Forum für Hydrologie und Wasserbewirtschaftung Heft 30.11, Beiträge zum Tag der Hydrologie am 24./25. März 2011 an der Technischen Universität Wien. TU Vienna.

Unbehauen, W., 1971. Die Hochwasserabflußverhältnisse der bayerischen Donau Hochwasser der Jahresreihe 1845/1965, München, Bayer. [The flood characteristics of the bavarian Danube, flood events between 1845 and 1965]. Bayer, Landesstelle für Gewässerkunde, Munich. (In German.)

Received 1 December 2015 Accepted 17 May 2016 